\section{Professor Frederico Simões Barbosa e sua contribuição à epidemiologia brasileira}

\author{
Professor Frederico Simões Barbosa and his \\ contribution to Brazilian epidemiology
}

\author{
Profesor Frederico Simões Barbosa y su \\ contribución a la epidemiología de Brasil
}

Moisés Goldbaum 1

Registrar uma homenagem à saudosa memória do professor Frederico Simões Barbosa, fundador e primeiro presidente de nossa associação, a Associação Brasileira de Saúde Coleitva (Abrasco), entidade cujas bandeiras de luta têm procurado honrar os ensinamentos do professor Frederico, como o conhecíamos, remete-nos a várias linhas tal sua fecunda contribuição ao desenvolvimento da pesquisa e educação em saúde no Brasil. Uma opção interessante e aqui assumida foi visitar e relembrar o artigo de sua coautoria com Herman Voss 1, versando sobre as formas clínicas da esquistossomose, o que nos leva a analisar sua obra e sua contribuição para o desenvolvimento da ciência em saúde no Brasil, em particular na epidemiologia das doenças endêmicas. De imediato, pode-se recuperar sua recomendação na elaboração de estudos epidemiológicos, registrada por Coutinho 2 (p. 428), que transcrevo: "trocar a complexidade pela simplicidade, a extensão pela profundidade, a rígida e cega padronização técnica pela criatividade, a alienação por uma visão comprometida com a comunidade". Esta é a sua marca e trajetória na busca de soluções para indagações e desafios que o processo saúdedoença permanentemente nos traz.

A este artigo, agregam-se as centenas de outros publicados e, no tema da esquistossomose, seleciono um, no qual ele registra, de forma impar e inédita, a competição entre caramujos transmissores de esquistossomose mansônica 3 . A citação desses dois artigos permite sintetizar e apreender o estilo que marcou uma época fecunda de emergência epidemiologia brasileira a partir de seus pesquisadores, cujo interesse de investigação estava voltado para as doenças de natureza infecciosas. Entre outras características dessa época, identificam-se os esforços para a descrição completa dos ciclos de doença, como, no começo do século passado, as notáveis análises da tripanosomíase americana realizadas por Carlos Chagas, louvadas no fascículo 4 do volume 37, de 2008, do International Journal of Epidemiology, dedicado especialmente à América Latina. Nessa perspectiva, pode-se afirmar que o professor Simões Barbosa ocupa, ao lado de Carlos Chagas e outros tantos pesquisadores brasileiros, especialmente Samuel Pessoa, que lhe serviu de inspiração, o espaço reservado àqueles que, vindos da área das doenças infecciosas e parasitárias, estabeleceram e deram sequência ao desenvolvimento da epidemiologia no país.

Os dois artigos citados anteriormente, agregado de seu extenso trabalho sobre a morbidade da esquistossomose ${ }^{4}$, compõem o exemplo de sua peculiar natureza investigativa. De um lado, a exploração da doença na sua perspectiva malacológica, produzindo conhecimentos para a aplicação e revisão de políticas de controle da população de caramujos e, consequentemente, de controle da doença, mesmo entrando em situações divergentes com renomados pesquisadores nacionais e internacionais 5. De outro lado, os trabalhos de natureza clínico-epidemio- 
lógica, que lhe permitiram verificar, no âmbito da comunidade, os graus de acometimento e a morbidade gerada pela infecção esquistossomótica. Ou seja, como salientado anteriormente, procurou, em suas pesquisas, preocupado com as questões "médico-sociais" e dadas as condições da época, responder de modo integrado e completo à história da doença. Essa dimensão holística da busca de compreensão das doenças, a partir desses pioneiros da epidemiologia brasileira, influenciou fortemente as futuras gerações que hoje compõem o grande e consolidado contingente de epidemiologistas nacionais, cuja produção científica vem se constituindo em significativos subsídios para a elaboração de políticas públicas em saúde.

Pode-se afirmar, acompanhando a trajetória do professor Frederico, que ele representa, ao lado dos pesquisadores originários da área de doenças infectoparasitárias, os inovadores e formadores da moderna epidemiologia brasileira, cujas bases, no Brasil, contemplam, de modo original e produtivo, o indissociável tripé: necessidades de saúde, produção de conhecimentos e atenção à saúde. Trata-se de uma ciência comprometida com a comunidade, como ele recomendava. Assim, é oportuno transcrever suas didáticas palavras ao analisar o papel das universidades e da pesquisa: "As universidades brasileiras têm papel de relevância. Sua missão não mais se assenta sobre o famoso tripé ensino/pesquisa/extensão. Criar e transmitir o saber são suas precípuas obrigações. Entretanto, essas atividades só serão válidas se estiverem comprometidas com o bem-estar social. A produção científica deve ser simultaneamente um bem cultural e um instrumento de trabalho socialmente comprometido. As atividades docente e científica são parte da sociedade e só poderão ser entendidas como instrumentos de realização de objetivos sociais bem determinados" 6 .

Tais afirmações tão relevantes e atuais constituem-se em diretrizes a serem seguidas e sua implementação e realização são as melhores homenagens que podemos prestar à memória deste magnífico e ilustre pesquisador/pensador brasileiro.
1. Barbosa FS, Voss H. Evolution of the clinical gradient of Schistosoma mansoni infection in a small town in north-eastern Brazil. Bull World Health Organ 1969; 40:966-9.

2. Coutinho EM. Frederico Adolfo Simões Barbosa. Rev Soc Bras Med Trop 2004; 37:427-8.

3. Barbosa FS. Possible competitive displacement and evidence of hybridization between two Brazilian species of planorbid snails. Malacologia 1973; 14:401-8.
4. Barbosa FS. Morbidade da esquistossomose. Rev Bras Malariol Doenças Trop 1966; (número especial):3-159.

5. Coimbra Jr. CEA. Uma conversa com Frederico Simões Barbosa. Cad Saúde Pública 1997; 13:145-55.

6. Barbosa FS. Pronunciamento do Prof. Frederico Simões Barbosa, ao receber da Universidade de Brasília o título de Professor Honoris Causa, em 7/11/1995. http://www.unb.br/unb/titulos/frede rico_simoes.php (acessado em 25/Abr/2016). 